Click www.researchjournal.co.in/online/subdetail.html to purchase.

International Journal of Commerce and Business Management Volume 10 | Issue 1 | April, 2017 | 42-47

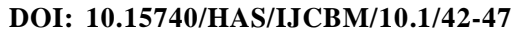

$\Rightarrow$ Visit us : www.researchjournal.co.in

RESEARCH PAPER

\title{
Agribusiness potential of sericulture in Karnataka
}

\author{
B. KRISHNAKUMARE, S. NIRANJAN AND SNEHA DOHARE
}

Received : 14.02.2017; Revised : 12.03.2017; Accepted : 24.03.2017

\begin{abstract}
Sericulture is a cottage based industry which combines both the features of agriculture and industry. India has tremendous potential for silk development but yet unexploited, however, development is not far away. It is one of the major employment generating sectors in the state and its growth has immense employment generation potential, particularly in rural Karnataka. This studyis an attempt to analyze the agribusiness potential of sericulture in Karnataka. The study explored that there is a huge improvement in area, production and also employment from 2008-09 to 2015-16. The cultivated area was only 177943 hectares in 2008-09, which has improved over the years and has reached 208947 hectares in 2015-16 with a compound annual growth rate of 2 per cent. Similarly, the production in Karnataka was also increased from 5949MT in 2003-04 to 9645MT in 2014-15 with CAGR of 4 per cent. 27 per cent of the families of Karnataka are contributing to the total families engaged in Indian sericulture industry. In the year 2014-15, earnings from export were about Rs.2829.94 crore but it was reduced to Rs. 2495.99 crore in the year 2015-16. The import earnings during the year 2015-16 was Rs. 1389.10 crore. Hence, it is revealed from the study that sericulture has a very high employment potential. It is the biggest employer in the country only next to handloom industry. It is ideally suited to generate jobs in the rural areas and particularly in the drought prone areas.Sericulture gains added importance in the context of growing unemployment, both disguised and seasonal. Most of the farmers in India are poor and are not employed throughout the year. Sericulture can provide subsidiary employment to such farmers and augment their in comes.
\end{abstract}

KEY WORDS : Sericulture, CAGR, Employment potential

How to cite this paper : Krishnakumare, B., Niranjan, S. and Dohare, Sneha (2017). Agribusiness potential of sericulture in Karnataka . Internat. J. Com. \& Bus. Manage, 10(1) : 42-47, DOI: 10.15740/HAS/IJCBM/10.1/42-47.

\section{MEMBERS OF THE RESEARCH FORUM}

Correspondence to:

B. KRISHNAKUMARE, College of Agribusiness Management, G.B.

Pant University of Agriculture and Technology, Pantnagar, UDHAM SINGH NAGAR (UTTARAKHAND) INDIA

Authors' affiliations:

S. NIRANJAN, Department of Agricultural Economics, College of Agriculture, VIJAYAPUR (KARNATAKA) INDIA

SNEHA DOHARE, College of Agribusiness Management, G.B. Pant

University of Agriculture and Technology, Pantnagar, UDHAM SINGH NAGAR (UTTARAKHAND) INDIA 